\title{
ON A SMALL COLLECTION OF MOLLUSCA FROM TIERRA DEL FUEGO.
}

By Edgar A. Sutth, I.S.O.

Read 16th June, 1905.

THE specimens under consideration formed part of the zoological collections brought home by Captain Richard Crawshay from Tierra del Fuego a few months ago. Considering the smallness of the collection it is interesting to find so large a proportion of novelties. This is accounted for from the fact that the island has never been thoroughly investigated for mollusca. The Wilkes Exploring Expedition (1838-1842) discovered a number of new forms, and the French Mission Scientifique du Cap Horn (1882-1883) collected a few more. Dr. R. O. Cunningham, during the voyage of H.M.S. "Nassau" (1866-1869), and Dr. R. W. Coppinger, during the survey of H.M.S. "Alert" in 1879-1880, made considerable collections of mollusca in the Straits of Magellan and Southern Patagonia, although not actually on the shores of the island. No special list of the mollusca of Tierra del Fuego has hitherto been published, ${ }^{1}$ so that the following may be regarded as the first instalment of such a catalogue. Captain Crawshay made no attempt at systematic shell-collecting, but merely picked up the few specimens that he came upon by chance. Consequently the small number of species obtained gives practically little idea of the probable richness or poverty of the fauna. The land shells at present known from the main and adjacent islands consist of about eight very small Helicoids and two or three species of Succinea. The only freshwater forms are two species of Limnaa, two speeies of Acyrogonia, a group allied to Limnaa, and one or two species of Chilina, besides that now described. This genus has not previously been recorded from the main island.

Among the marine forms occurred a single worn shell (Fig. I), of much interest, apparently belonging to a new genus. It has a subfossilized appearance, but my colleague, Mr. R. Bullen Newton, has failed to recognize it as a palæontological specimen. The rest of the collection consists of well-known Patagonian and Magellanic forms, such as Trophon, Bullia, Photinula, Nacella, Modiolarca, etc.

With reference to the localities quoted in the following pages, Car,tain Crawshay has supplied these notes:-

" "San Sebastian Beach' refers to the sea-shore of San Sebastian Bay. 'Rio McClelland' has a wider sense than merely the mouth of the river, and refers rather to the southern shore of Useless Bay, working from the Rio McClelland as a base.

1. Most of the known species, however, are quoted by Mabille and Rochebrune in their account of the Mollusca of the Mission Scientifique du Cap Horn. 
"The land shells from there were from the forested valley of the river, where they are usually found under decayed tree-trunks, but sometimes in the open.

"The Rio Marazzi flows into the head of Useless Bay. The freshwater shells from this river were taken about two miles inland, where it is perfectly fresh."

The following notes on the physical features of the island have also been furnished by Capt. Crawshay:-

"The shores of Tierra del Fuego afford a weird and fascinating study, for wind and wave have worked extraordinary results. Common objects are the bones of whales, carcases of sea-lions and guanacos, ships' boats, spars, rudders, and other wreckage, treetrunks, and endless odds and ends of timber in general.

"The line of the last high tide is marked by huge masses of seaweed, with quantities of mussel- and limpet-shells. The prevailing character of the beach in Admiralty Sound is grey shingle, with stretches of large, round, water-worn stones, similar to those of the British coast. In San Sebastian Bay, on the Atlantic side of the island, the sea recedes an immense distance at low tide, laying bare miles and miles of muddy sandflats. There I found several shells which do not seem to occur on the opposite side of the island. Shells are to be seen inland in Tierra del Fuego, on the surface and below it, on the downs some 200 feet above the sea, both on the east and west coasts of the island, thrown up by the burrowing Ctenomys, but whether these represent the work of Indians in bygone times or natural sea-deposits, I am not prepared to say. The shells thus thrown up are almost invariably limpets."

\section{Marine Species.}

1. Trophon Geversianus (Pallas).

Hab.-Rio McClelland, west coast of the island.

2. Trophon muriciformis (King).

Hab.-Rio McClelland, Useless Bay, west coast of the island.

3. Acanthina calcar (Martyn).

Hab.-Rio McClelland and Admiralty Sound, west side of the island.

\section{Bullia squalida (King).}

Bullia squalida, King: Reeve, Con. Icon., vol. iii, pl. iv, fig. 26.

Hab.-San Sebastian Bay, east coast of the island.

5. Natica atrocyanea, Philippi.

Natica atrocyanea, Philippi: Conch. Cab., p. 53, pl. viii, fig. 7 ; Abbild., vol. ii, p. 41, pl. ii, fig. 1; Tryon, Man. Conch., vol. viii, p. 37 , pl. xiv, fig. 21 .

Hab.--San Sebastian Beach (Crawshay); Straits of Magellan (Philippi).

It is curious that the outer cretaceous coating of this shell is liable to te dissolved, leaving the deep purple under-layer exposed. 


\section{6. Рhotindla Crawshayi, n.sp. Fig. iI.}

Testa imperforata, turbinata, saturate lilacea; anfractus 6 (?), penult. et antepenult. sulcis spiralibus $3-4$ sculpti, convexi, ultimus supra et infra obsolete sulcatus, infra suturam leviter impressus, ad peripheriam rotunde subangulatus, incrementi lineis tenuibus perobliquis striatus, infra medium lineis paucis concentricis saturatioribus pictus, cirea regionem umbilici albus ; apertura obliqua, intus obsolete sulcata; columella incrassata, reflexa, appressa, alba, callo tenui labro juneta.

Diam. maj. 21, min. $18 \mathrm{~mm}$; ; alt. $22 \mathrm{~mm}$.

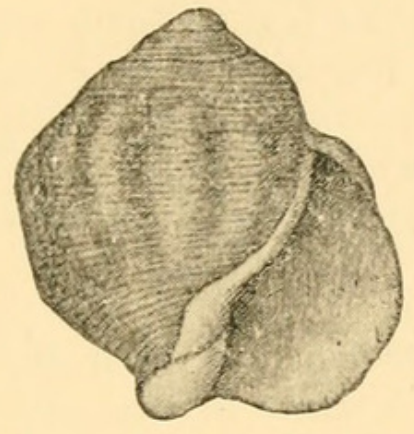

I

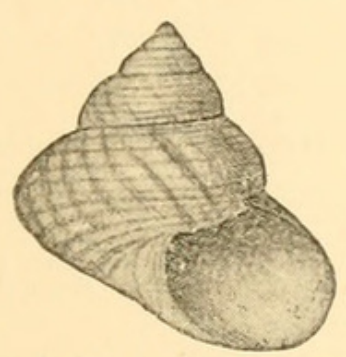

II

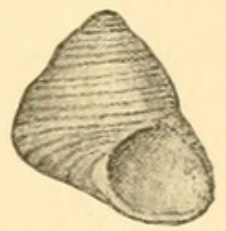

III

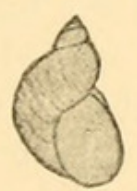

IV

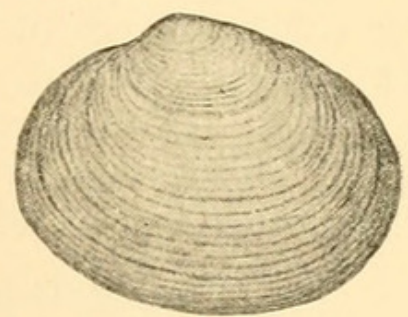

$\mathrm{V}$

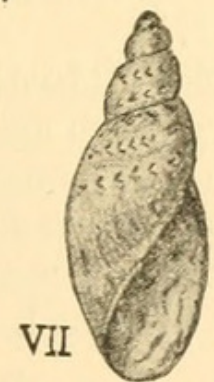

Fig. I. Gen. et sp. - ?

,, II. Photinula Crawshayi, n.sp.

,, III. ,, roseolineata, n.sp.

,, IV. Succinea ordinaria, n.sp.

,, v. Chione Fuegiensis, n.sp.

,, vi. Mactra Fuegiensis, n.sp.

,, vir. Chilina Fuegiensis, n.sp.

\section{Hab.-Rio McClelland, Useless Bay.}

In some respeets this species approaches $P$. Hyadesi of Rochebrune and Mabille, ${ }^{1}$ but the spire is more elevated, the penultimate whorl larger and more convex, and the colour different.

The single specimen has the apex broken away so that the number of whorls is given only approximately. The antepenultimate whorl 
has around the lower part three distinct rounded spiral liræ which also extend on to the penultimate and gradually die out upon the last. The general tone of the shell is a deep lilac, but oblique streaks of a darker tint at irregular intervals are noticeable upon the body-whorl, the base of which exhibits some dark and light concentric zones, excepting around the umbilical region, which is white. The faint sulci within the aperture correspond with the almost obsolete external spiral liræ.

7. Photinula roseolineata, n.sp. Fig. imi.

Testa turbinata, imperforata, alba, lineis gracilibus spiralibus roseis picta, sub tegmine cretaceo lævi spiraliter tenuiter sulcata; spira convexe conica, ad apicem obtusa; anfractus 5 celeriter accrescentes, parum convexi, ultimus ad peripheriam rotunde obsolete angulatus, antice vix descendens, infra suturam versus aperturam leviter concave impressus, infra medium subplanatus ; apertura obliqua, intus obsolete sulcata ; columella oblique arcuata, incrassata, reflexa, appressa, alba.

Diam. maj. 15 , min. $14.5 \mathrm{~mm}$; alt. $15 \mathrm{~mm}$.

Hab.-San Sebastian Beach.

This species is well characterized by its peculiar form and colour. The outer calcareous coating of the shell, in which are the colour-lines, is almost smooth externally, but the pearly layer beneath is rather strongly sulcate. This is very evident where the outer layer has been chipped off. The penultimate whorl has four rose-coloured spiral lines and the last nine, four of which are upon the lower surface.

\section{Photinula carulescens (King).}

Trochus carulescens, King: Philippi, Conch. Cab., p. 250, pl. xxxvii, fig. 11.

Hab.-San Sebastian Beach.

One very large specimen is $29 \mathrm{~mm}$. in diameter.

A second specimen is somewhat different, having the body-whorl more convex above and the base less impressed in the umbilical region.

I cannot agree with Pilsbry that this species is only a variety of the $P$. taniata of Wood. In my opinion they are quite distinct.

Hab.-Rio MeClelland.

9. Рhotinula violacea (King).

10. Nacella mytilina (Helbling).

\section{Hab.-Rio McClelland.}

\section{Chione Fuegiensis, n.sp. Fig. v.}

Testa parva, ovata, mediocriter compressa, inæquilateralis, dilute fuscescens; margo dorsi posticus declivis, rectiusculus, anticus brevior, æqualiter descendens, vix curvatus; latus anterius late rotundatum, posterius paulo angustius; valvæ crassæ, concentrice sulcatæ, sulcis hic illic cæteris profundiorıbus; pagina interna in medio albida, marginem minute crenulatum versus violacea; lunula angusta, elongata, linea incisa circumscripta; cicatrix antica elongata, irregulariter ovata, postica subpiriformis; sinus pallii brevis, subacutus.

Long. $25 \cdot 5$, alt. $19 \cdot 5$, diam. $11 \mathrm{~mm}$.

Hab.-Rio McClelland. 
This species is allied to Chione crassa of Quoy \& Gaimard from New Zealand, but is more compressed, and ovate, the umbones being less prominent. The concentric sculpture also is hardly so strong as in that species. Only a single specimen was collected. The ligament, $6 \mathrm{~mm}$. in length, is not prominent above the valves, being situated in a narrow but deep escutcheon. Besides the concentric sulci, the surface exhibits excessively minute radiating striæ, only visible under a strong lens. The hinge consists of three teeth in each valve, the central one in the left valve and the two posterior in the right being somewhat bifid.

\section{Mactra Fuegiensis, n.sp. Fig. vi.}

Testa trigono-ovata, inæquilateralis, tenuis, alba, periostraco flavescente induta, concentrice tenuiter striata, carina ab umbone ad marginem posticum instructa; margo dorsi posticus arcuatim declivis, anticus æque descendens sed fere rectus; latus anticum acute rotundatum, posticum paulo latius; margo ventralis late curvatus vel in medio subrectus; umbones approximati, ad apicem leviter erosi ; pagina interna alba, cretacea; cicatrices et linea pallii nitentes; cicatrix antica magna, piriformis, postica major, latior; sinus linguæformis, subprofundus.

Long. $51 \cdot 5$, alt. $37 \cdot 5$, diam. $21 \mathrm{~mm}$.

$H a b$.-San Sebastian Beach.

This species of Mactra appears to be different from any of the known forms from South Patagonia, namely, Mactra edulis, King; exalbida, Gray; Patagonica, d'Orbigny; marcida, Gould ; levicardo, Smith; and Jousseaumi, Mabille \& Rochebrune. It is rather like the last-named species as figured by Pilsbry (Amer. Journ. Sci., 1899, vol. vii, pl. i, figs. 1-3), but the umbones are less prominent, the anterior end is more pointed, and the size is smaller. The epidermal carina down the posterior side also tends to distinguish it. Mabille \& Rochebrune describe their shell as "solidula" and "intus roseo-alba," whereas the present species is light and thin, and dirty-whitish within.

The hinge is normal, but the lateral teeth are small and rather close up to the cardinals. The small external or marginal ligament is divided off from the resilium by the continuation of the single posterior lateral tooth of the left valve and the lower of the two of the right valve. The concentric sculpture upon the umbones, in fresh, unworn shells, is regular and thread-like, becoming finer as the shell increases. The epidermis is very finely lamellated, and somewhat wrinkled down the posterior side behind the radiating ridge. A second faint ridge is more or less evident down this part of the valves.

\section{Darina solenoides (King).}

Hab.-San Sebastian Beach (Crawshay); Port Famine, Straits of Magellan (King).

The name solenoides was changed by Fischer ${ }^{1}$ to Kingi, on the ground that Lamarck had already used it in the genus Lutraria, of 
which Fischer considered Darina merely a section. If, however, we consider it generically distinct, the alteration becomes unnecessary.

14. Mrtilus Fischerianus, Canefri, var. (?).

Hab.-San Sebastian Beach.

A few small specimens which differ from the form figured by Canefri in having the ventral outline rather straighter, and the posterior adductor scar is somewhat smaller.

15. Mrtilus (Aulacomya) Magellanicus, Chemnitz.

Hab.-San Sebastian Beach.

\section{Brachydontes sp.}

Hab.-San Sebastian Beach.

A single valve only, which I cannot identify at present. In shape and size very like $B$. Darwinianus, d'Orbigny, but more strongly radiately sculptured.

Hab.-Rio McClelland.

17. Modiolarca trapezina (Lamarck).

The specimens from this locality are of a deep purple-brown, which externally is somewhat obscured by a thin olivaceous periostracum. This species was figured by Küster in 1841 (Con. Cab., pl. vi, figs. 16, 17) as Modiola trapezina. The same figures have since been quoted by Clessin in the same work, Mytilidæ, p. 155, as representing Dacrydium vitreum, a minute northern molluse, from which, of course, it is quite distinct.

Attention may also be directed to seven species (?), all from the same locality, Orange Bay, described and figured by Mabille \& Rochebrune (Miss. Cap Horn, Moll., pp. 121-124, pl. vii, figs. 1a-7b). Personally I must confess to being unable to appreciate the specific value of these so-called species. Orange Bay is the same as Orange Harbour, where so many shells were collected by the United States Exploring Expedition under Commander C. Wilkes in 1838-1842. It is situated on the eastern side of Hoste Island, one of the smaller islands to the south of Tierra del Fuego.

\section{Land and Fresh-water Species.}

Only four land species and one from fresh water were obtained, namely, two forms of Succinea, two Helicoids, and a new species of Chitina.

\section{Succinea Patagonica, Smith, var.}

Hab.-Rio McClelland.

A little smaller and narrower than the types collected by Dr. Coppinger. Perhaps the same as S. Lebruni, Mabille.

19. Succinea ordinaria, n.sp. Fig. iv.

Testa imperforata, oblonga, tenuis, subpellucida, flavescenti-cornea, versus apicem pallide rufescens; anfractus $3-3 \frac{1}{2}$ perconvexi, celeriter accrescentes, sutura obliqua profunda sejuncta, lineis incrementi subrugosa striati; apertura ovata; peristoma tenue, margine columellari callo tenui labro juncta. 
Long. $10 \cdot 25$, diam. $6 \mathrm{~mm}$.; apertura $6 \mathrm{~mm}$. longa, 5 lata. Hab.-Admiralty Sound.

Apparently very like S. Lebruni, Mabille, ${ }^{1}$ but without the sanguineous apex, and rather more coarsely sculptured.

\section{Hab.-Rio McClelland.}

20. Amphidoxa (Stephanoda) lyrata (Gould).

Two specimens apparently belonging to this species, which was collected originally by Couthony at Orange Harbour on the eastern side of Hoste Island, one of the detached islands south of the main island.

\section{Payenia (?) sp.}

A single immature shell from Rio McClelland may belong to this genus, created by Mabille \& Rochebrune ${ }^{2}$ for the Helix saxatilis of Gould from Orange Harbour.

\section{Chilina Fuegrensis, n.sp. Fig. vir.}

Testa angusta, elongata, tenuis, sub tegmine terreno nigro olivacea, lineis rufis longitudinalibus undulatis picta, lineis incrementi tenuibus striata, striisque spiralibus minutis obscure sculpta; anfractus 5-6 valde convexi, ultimus elongatus, antice oblique descendens; apertura elongata, inverse auriformis, intus plus minus purpureo tincta et strigata; columella alba, plica tenui obliqua supra instructa, antice reflexa, superne callo tenui labro juncta.

Long. 24, diam. $10 \mathrm{~mm}$; ; apertura $13.5 \mathrm{~mm}$. longa, $5 \cdot 5$ lata.

Hab.-Rio Marazzi, Useless Bay.

This species, the only one recorded from Tierra del Fuego, is remarkable on account of its slender form. All the specimens were coated with a black earthy deposit, which can easily be removed with a little diluted hydrochloric acid. Some examples are shorter than others, on account of the spire being less produced. In these specimens the mouth is consequently longer in proportion to the whole length of the shell. The following are the dimensions of such a specimen: length, $19 \mathrm{~mm}$. ; length of aperture, $12 \mathrm{~mm}$.

1 Mission Scient. Cap Horn, Moll., p. 14, pl. vi, fig. 4.

2 Ibid., p. 18. 


\section{$2 \mathrm{BHL}$ Biodiversity Heritage Library}

Smith, E. A. 1905. "ON A SMALL COLLECTION OF MOLLUSCA FROM TIERRA

DEL FUEGO." Proceedings of the Malacological Society of London 6, 333-339.

View This Item Online: https://www.biodiversitylibrary.org/item/52315

Permalink: https://www.biodiversitylibrary.org/partpdf/202894

\section{Holding Institution}

Smithsonian Libraries

\section{Sponsored by}

Smithsonian

\section{Copyright \& Reuse}

Copyright Status: Public domain. The BHL considers that this work is no longer under copyright protection.

This document was created from content at the Biodiversity Heritage Library, the world's largest open access digital library for biodiversity literature and archives. Visit BHL at https://www.biodiversitylibrary.org. 